U. S. Department of the Interior

U. S. Geological Survey

\title{
The Santa Cruz - Tarija Province of Central South America: Los Monos - Machareti(!) Petroleum System
}

\author{
by
}

Sandra J. Lindquist ${ }^{1}$

\section{Open-File Report 99-50-C}

This report is preliminary and has not been reviewed for conformity with the U.S. Geological Survey editorial standards or with the North American Stratigraphic Code. Any use of trade names is for descriptive purposes only and does not imply endorsement by the U.S. government.

\section{8}

${ }^{1}$ Consulting Geologist, Contractor to U. S. Geological Survey, Denver, Colorado 


\title{
The Santa Cruz - Tarija Province of Central South America: Los Monos - Machareti(!) Petroleum System ${ }^{2}$
}

\author{
Sandra J. Lindquist, Consulting Geologist \\ Contractor to U.S. Geological Survey, Denver, CO
}

\section{FOREWORD}

This report is a product of the World Energy Project of the U.S. Geological Survey, in which the world has been divided into 8 regions and 937 geologic provinces for purposes of assessment of global oil and gas resources (Klett and others, 1997). These provinces have been ranked according to the discovered petroleum volumes within each; 76 "priority" provinces (exclusive of the U.S. and chosen for their high ranking) and 26 "boutique" provinces (exclusive of the U.S. and chosen for various reasons) were selected for appraisal of oil and gas resources. The petroleum geology of these non-U.S. priority and boutique provinces is described in this series of reports. Assessment results will be released in a later report, if such results are not reported herein.

The Total Petroleum System concept is the basis for this assessment. A total petroleum system includes the essential elements and processes, as well as all genetically related hydrocarbons, that occur in petroleum shows, seeps and accumulations (discovered and undiscovered), whose provenance is a pod or closely related pods of mature source rock (concept modified from Magoon and Dow, 1994). The minimum petroleum system is that portion of the total petroleum system for which the presence of essential elements and processes has been proved. The assessment unit is a mappable volume of rock within the total petroleum system, sufficiently homogeneous in terms of geology, exploration strategy and risk characteristics to constitute a single population with respect to criteria used for the chosen methodology of resource assessment. Assessment units are considered established if they contain more than 13 fields, frontier if they contain 1-13 fields, and hypothetical if they contain no fields.

A unique, eight-digit numeric code identifies each assessment unit with respect to region, province, and petroleum system. The first digit is the region number, the next three digits the province number, the next two digits the total petroleum system number, and the final two digits the assessment unit number. The codes for the regions and provinces were established, listed and mapped in Klett and others, 1997.

\begin{abstract}
The Los Monos - Machareti(!) total petroleum system is in the Santa Cruz - Tarija Province of Bolivia, Argentina and Paraguay. Province history is that of a Paleozoic, intracratonic, siliciclastic rift basin that evolved into a Miocene (Andean) foreland fold

${ }^{2}$ Los Monos - Machareti(!) Total Petroleum System (\#604501); Santa Cruz - Tarija Province (\#6045); South America (Region 6); Bolivia, Paraguay, and Argentina
\end{abstract}


and thrust belt. Existing fields are typified by alternating reservoir and seal rocks in postOrdovician sandstones and shales on anticlines. Thick Devonian and Silurian shale source rocks, depositionally and erosionally confined to this province, at a minimum have generated 4.1 BBOE known ultimate recoverable reserves (as of 1995, 77\% gas, $15 \%$ condensate, $8 \%$ oil) into dominantly Carboniferous reservoirs with average $20 \%$ porosity and 156 md permeability. Major detachment surfaces within the source rocks contributed to the thin-skinned and laterally continuous nature of the deformation. Tertiary foreland burial adequate for significant source maturation coincided with the formation of compressional traps. Further hydrocarbon discovery in the fold and thrust belt is expected. In the foreland basin, higher thermal gradients and variable burial history combined with the presence of unconformity and onlap wedges - create potential there for stratigraphic traps and pre-Andean, block-fault and forced-fold traps.

\section{INTRODUCTION}

The Santa Cruz - Tarija Province of Bolivia, Argentina and Paraguay is named for two larger cities that approximately define its north-south geographic limits within the eastern Andean region of central South America. The term Chaco-Tarija used throughout this report denotes the evolved Paleozoic-to-Recent Bolivian-Paraguayan basin that covers most of the province and also extends farther northwest into Peru. This Chaco-Tarija basin should not be confused with a similar terminology, the Chaco-Parana basin, which is to the south and east in Argentina.

One petroleum system, Los Monos - Machareti(!), with Siluro-Devonian shale source rocks and Carboniferous siliciclastic reservoirs (Figure 1), dominates this foreland fold and thrust belt. Primary Devonian Los Monos and secondary Silurian Kirusillas / El Carmen shales attain a maximum 4-km composite thickness and have type II to type III kerogen with maximum 2 wt \% total organic carbon (TOC). Other significant reservoirs are Devonian (especially in the northwestern part of the province), with lesser Tertiary, Cretaceous, Permo-Triassic and Silurian representation as reservoir rocks. There are oil shows in Cambrian and older rocks along the northeastern edge of the province that could belong to source rocks older than Siluro-Devonian.

A book (A.A.P.G. Memoir 62) published jointly by the American Association of Petroleum Geologists, Yacimientos Petroliferos Fiscales Bolivianos, and Academia Nacional de Ciencias de Bolivia (Tankard and others, 1995) contains recent syntheses of South American geology and is referenced extensively here. Quantitative production data are derived from Petroconsultants (1996). The stratigraphic equivalents chart in this report (Figure 1) is composited from many references to approximately equate the range of stratigraphic nomenclature in use. It is not intended to be precise with respect to absolute geologic age.

\section{PROVINCE GEOLOGY}

\section{Province Boundary}

The Santa Cruz - Tarija Province is a subequant, 400,000-sq-km area, comprising parts of southeastern Bolivia (57\% of the province), western Paraguay (33\% of the province), 
Figure 1. Chart of stratigraphic equivalents for Santa Cruz - Tarija Province.

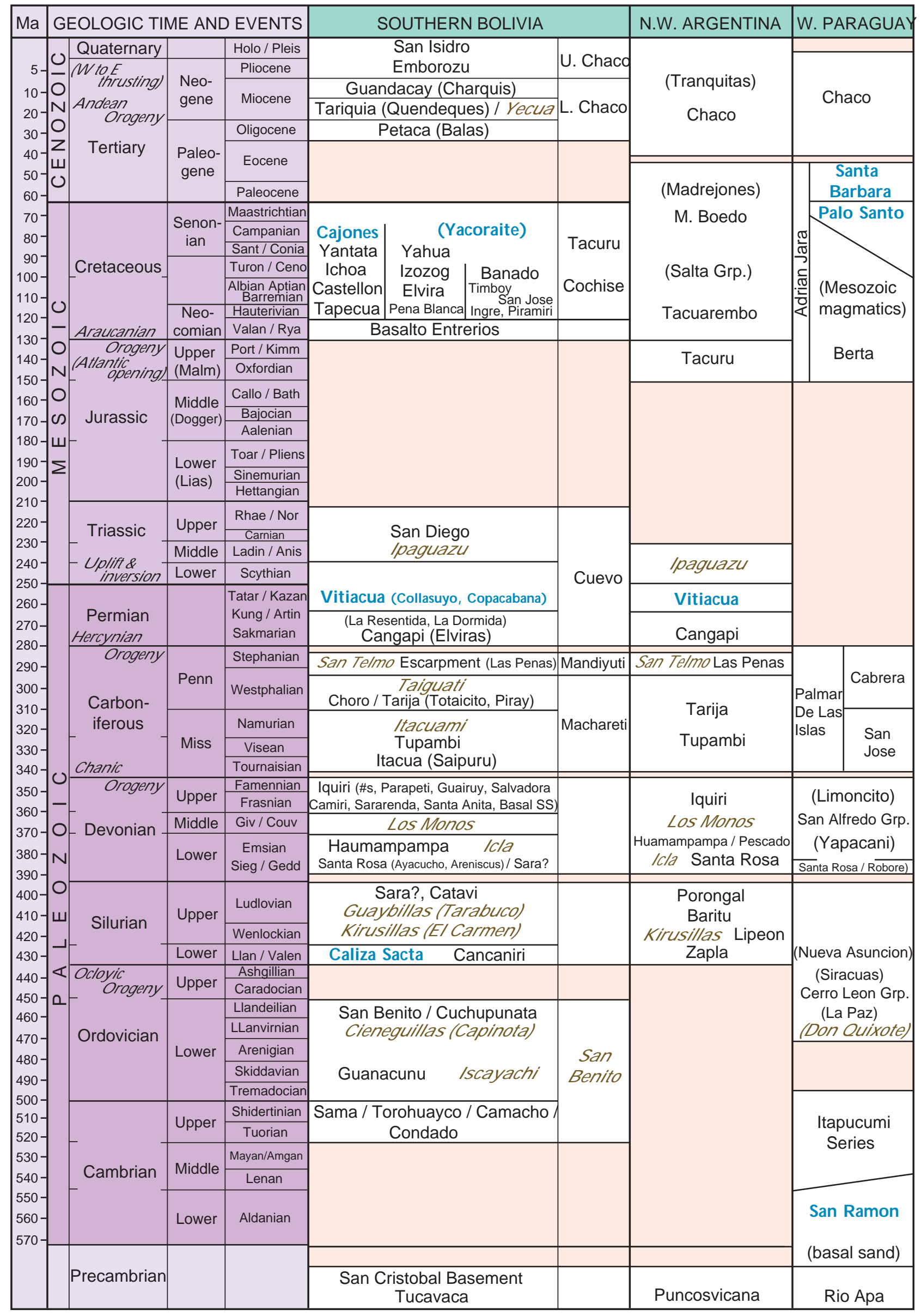

Explanation: Mostly Shale Mostly Carbonate 
northern Argentina (5\% of the province), and Brazil (5\% of the province) (Figures 2a and 2b). Maximum north-south extent is $700 \mathrm{~km}$ in the western (Andes) mountains, with an east-west dimension averaging $700 \mathrm{~km}$.

\section{Geographic Setting}

A salient of the thin-skinned fold and thrust belt, called "sub-Andean" and located east of the Main Andean frontal thrust, comprises the western part of the province. Excluded are - each successively farther west - Bolivia's thick-skinned, thrusted, basement-involved eastern Cordillera (oriental), Bolivia's altiplano, and Chile's western Cordillera (occidental) (Figure 3). "Basement" here includes non-reservoir, Cambro-Ordovician and older rock. The sub-Andean trend is approximately ten times the area of the productive Absaroka trend in the western United States fold and thrust belt.

Included to the northwest is the thrust front bend at Boomerang Hills (Figure 2a), an oblique-ramp transfer zone caused by the non-orthogonal relationship of a northwardtruncating Paleozoic sedimentary wedge to eastward compressional forces. Included to the south is a portion of Argentina's Northwestern basin. The Chaco plain is a Quaternary veneer over the Chaco-Tarija foreland basin (northeast Curupaity and southwest Carandaity sub-basins separated by the Paraguayan central Chaco high). The Brazilian (Guapore) shield deforms the north-northeastern province edge with block faulting (Sierra Chiquitanas) and exposes Precambrian section, as does the Asuncion arch near the Paraguay River on the east. To the south is the subsurface Michicola arch.

\section{$\underline{\text { Political Entities }}$}

Governments of the Santa Cruz - Tarija Province are relatively stable, with current or former national oil companies and a history of international cooperation with industry and academia.

\section{Geologic Setting}

Santa Cruz - Tarija has a history of episodic extension and compression resulting from the complex tectonic history along the western margin of South America. Sedimentation patterns and tectonic style intertwined repeatedly, and structural elements were reactivated. The Brazilian shield and Asuncion arch were persistently exposed.

"Basement" is heterogeneous terrane accreted onto southwestern Gondwana during late Precambrian through early Paleozoic time when it was in a polar setting (Williams, 1995; Eyles and others, 1995). The Paleozoic intracontinental Chaco-Tarija basin of Bolivia and Paraguay overlies the suture of the Arequipa massif to the Gondwanan Brazilian shield. Extensive Cambro-Ordovician rifting resulted in deposition of a maximum $7 \mathrm{~km}$ of marine rocks, influenced by northwest-southeast and northeast-southwest structural trends (Wiens, 1995). Much of the Arequipa source area would eventually translate southward (Carboniferous) to become Patagonia and part of Antarctica (Williams, 1995).

The late Ordovician Ocloyic orogeny resulted from island arc accretion to the Pampean terrane south of Chaco-Tarija. The orogeny interrupted rift deposition with inversion and 


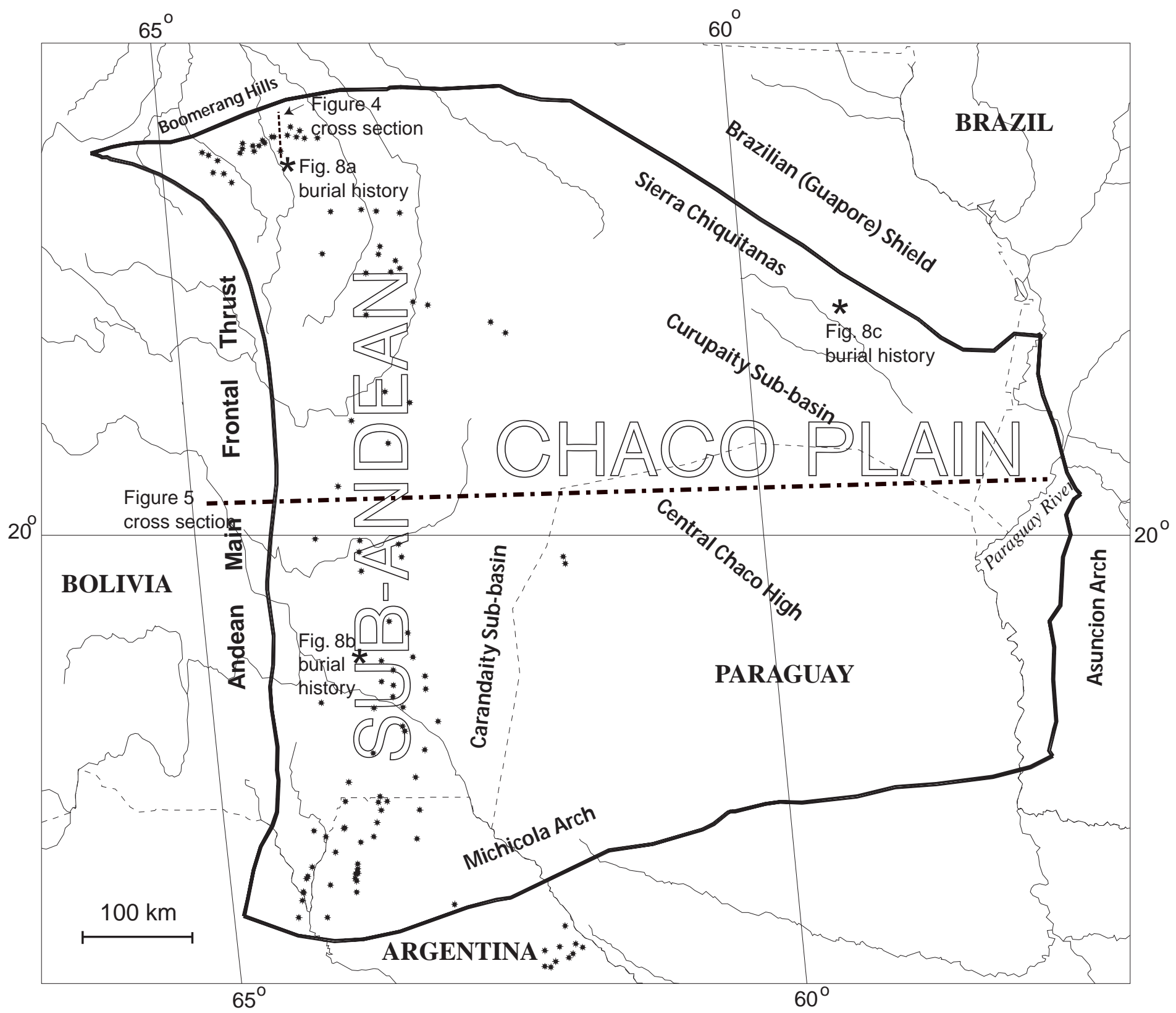

Figure 2a. Location map and geographic features of Santa Cruz - Tarija Province.

\section{EXPLANATION}

- Rivers

* Location of burial history curves

- Santa Cruz - Tarija province boundary

- Country Boundary

* Field Centerpoints

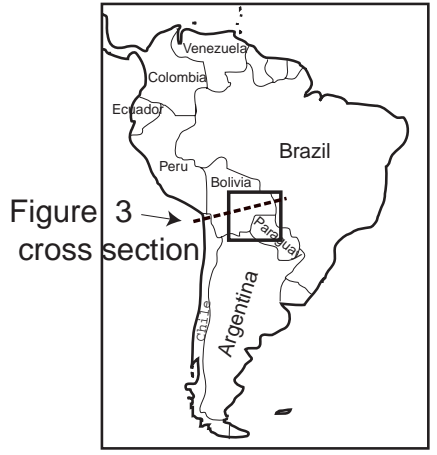




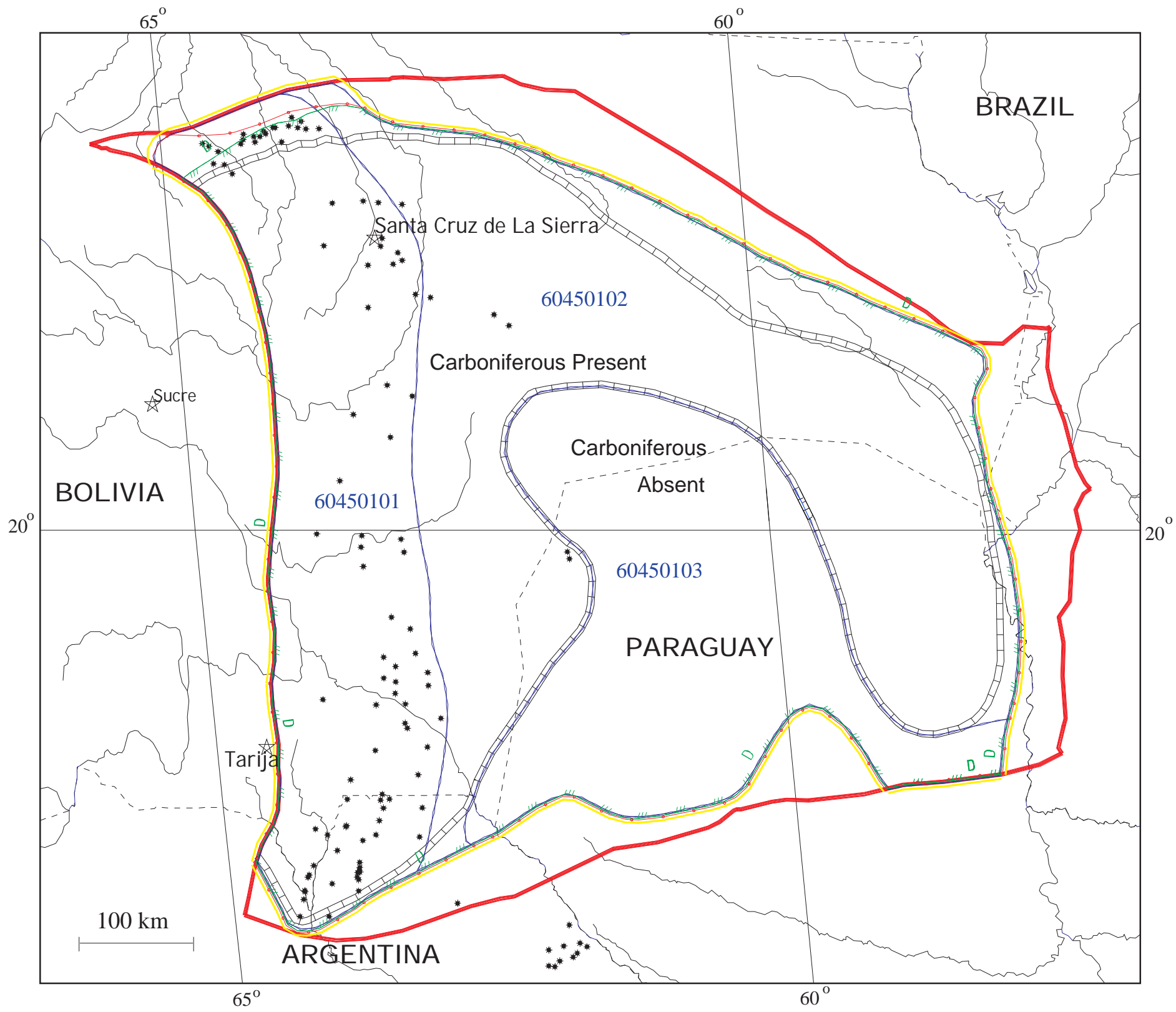

Figure 2b. Petroleum systems and assessment units of Santa Cruz - Tarija province \#6045.

\section{EXPLANATION}

- Rivers

$\square$ Carboniferous zero edge

- Santa Cruz - Tarija province boundary

- Country Boundary

* Field centerpoints
Assessment units

Minimum Petroleum System boundary

Total Petroleum System boundary

Pod of active source rocks boundary (Devonian zero edge) Tics indicate side of their presence 


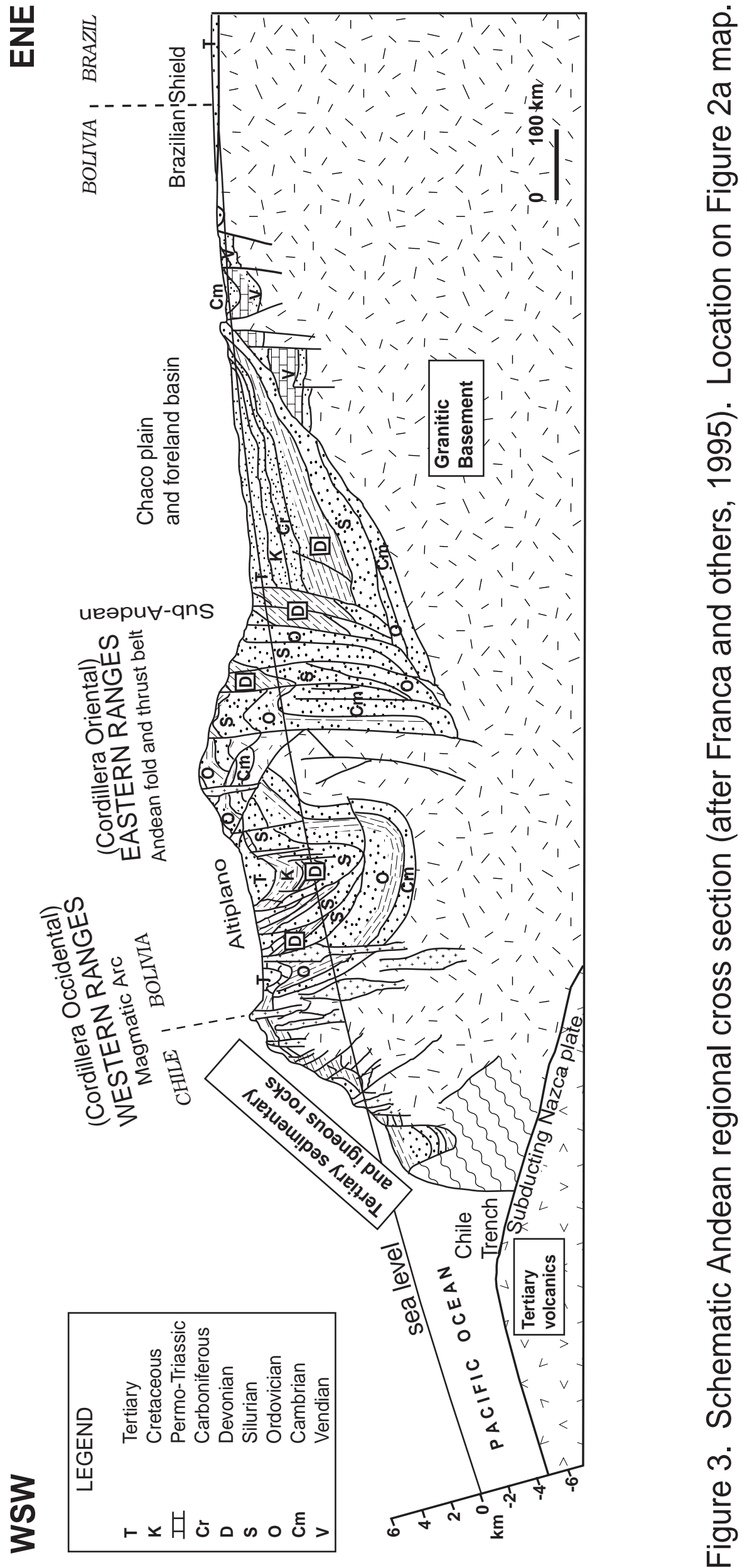


resulting unconformity at the Ordovician-Silurian boundary. Silurian Chaco-Tarija rifting resumed at a slower rate, and marine conditions became suitably anoxic for deposition of the Kirusillas / El Carmen shale source rocks.

Devonian warmer climate and increased subsidence - from active oceanic plate subduction to the west - resulted in another several-thousand meters of marine sedimentary record, including the middle Devonian Los Monos shale source rocks. More tectonic activity to the southwest (late Devonian Chanic orogeny) was recorded as another Chaco-Tarija unconformity when the Chilenian terrane was emplaced and Arequipa began its translation southward.

Carboniferous major global plate interactions signaled the completed assembly of Pangea and formed several intracratonic highlands in South America, including the Asuncion arch to the east and the remaining Arequipa massif bordering Chaco-Tarija to the west. At $30^{\circ}$ south latitude, these mountains were often glaciated, and the Carboniferous rock record in Chaco-Tarija comprises "glacially influenced" (terminology of Eyles and others, 1995) fluvial to turbidite deposits filling topographic relief as great as 500 meters.

Warmer Permian climate coincided with another orogenic episode of uplift and inversion in southwestern Gondwana. Chaco-Tarija experienced both deposition and erosion, and a restricted marine seaway with some carbonate deposition extended from the northwest. Triassic deposition was sparse, and a subsequent hiatus lasted from $210 \mathrm{Ma}$ through the Jurassic period to $130 \mathrm{Ma}$.

The late Jurassic Araucanian orogeny marks the opening of the south Atlantic, separating Africa from South America. Uplift of the southern Michicola arch, the northern terminus of a major Cretaceous (Lomas de Olmedo) graben system south of this province, resulted in the erosion there of much Paleozoic section, including the source rocks. A similar situation existed at Boomerang Hills to the north (Figure 4). Subsequent impact during Andean (Tertiary) thrusting was to laterally terminate the thin-skinned thrusts and folds where these truncations and loss of prominent detachment surfaces occur.

Cretaceous extension affected Chaco-Tarija with southeasterly directed transgression. Late Cretaceous to late Tertiary, west-to-east propagating thrusts (Andean orogeny) created the Andes mountains, loading the easterly Chaco plain into a flexural foreland basin and forebulge/backbulge complex that migrated eastwardly through time (Horton and DeCelles, 1997; Dunn and others, 1995) (Figure 5). The sub-Andean part of the deformation initiated in late Oligocene time. A wedge of Cenozoic continental sedimentation subsequently filled the foreland. Buried, growing thrust structures underlie the westernmost Chaco-Tarija basin east of the Andes Mountain topographic front. Tectonic shortening ranges laterally from tens to several hundreds of kilometers.

\section{Province Exploration History}

Nine hundred eighty-two total wells penetrated this province as of 1995 (Petroconsultants, 1996), with 715 in Bolivia, 229 in Argentina, 36 in Paraguay, and two in Brazil (both stratigraphic tests). 


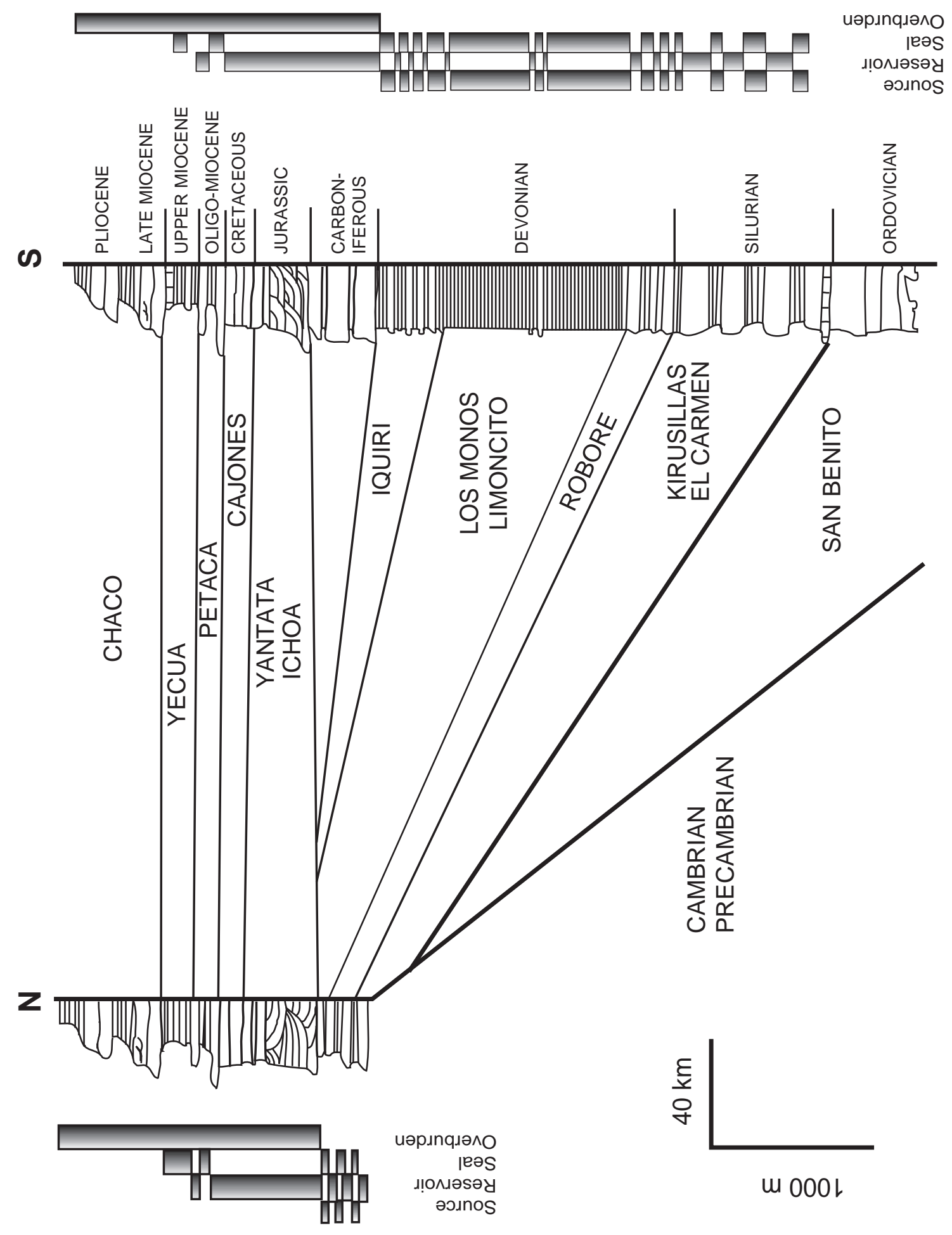

ค่

$\frac{\omega}{d}$

든

命

高

흥

है

บ

응

진

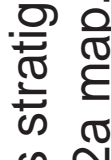

क N

皕 익

음 으

전

ㅎ․ㄷ

ㅇํㅇ

$\infty \frac{c}{\infty}$

하 
U
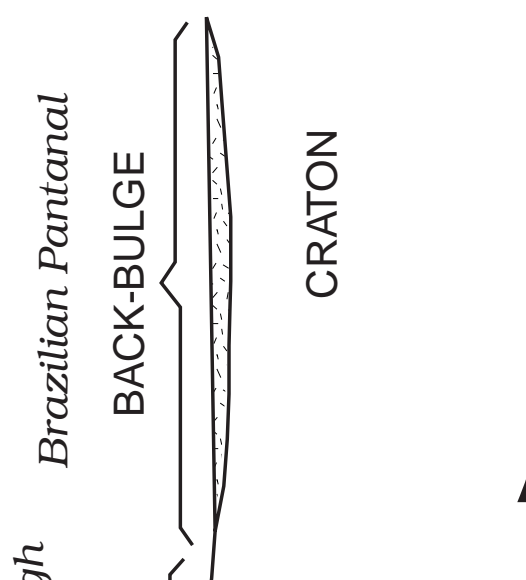
Bolivia's first wildcat exploratory well, along the central mountain front, failed in 1914 (Figure 6). Exploration activity continued ten years later with another well (oil show) in the same area, and two others at the southern border with Argentina (one with an oil show and the other a discovery of Bermejo field). One Argentina wildcat failure in 1920 was followed by discovery of the Agua Blanca field, on trend with Bermejo, in 1926. The largest field in the province, Argentina's Ramos (containing both oil and gas), was discovered in 1928.

Argentina's total drilling (both exploratory and development wells) has been modest but continuous - increasing through the early 1940s to approximately 5 wells/year, waning for the next twenty years with 1-2 wells/year, increasing in the mid to late 1960s with 3-6 wells/year, waning again through most of the 70s decade, and regularly represented by 19 wells/year for the last 15 years. Argentina has 27 fields with 58 successfully completed wells (Petroconsultants, 1996).

In contrast, Bolivia's total drilling (both exploratory and development wells) ceased from the early 1930s until the late 1940s. From 1958 through the mid 70s, drilling surged with 10-20 wells/year, doubled to 20-40 wells/year for the next decade, and has varied from 525 most recently. The second largest province field, Bolivia's Rio Grande (containing both gas and condensate), was discovered in 1961. The first Boomerang Hills discovery was in 1968. Bolivia currently has 77 fields with nearly 350 successfully completed wells (Petroconsultants, 1996).

Paraguay, in the foreland-basin part of this province, was first drilled in 1947, three years after seismic data first were acquired. Although drilling shows encompass a large area, just two producing fields exist in the northwesternmost corner of the country.

\section{PETROLEUM OCCURRENCE}

\section{Location of Fields and Seeps}

Seeps occur in the sub-Andean trend, where Devonian through Tertiary rocks crop out, and along the northeastern border of the province within Cambrian and older limestones. Most discovered fields are in sub-Andean reservoirs (Figure 2a) ranging from Silurian to Tertiary in age. All fields and shows - possibly except for the Cambrian seeps - are where Devonian source rocks are present.

The western sub-Andean is highly oil prone, with fields typically in oldest reservoir rocks. In contrast, the eastern sub-Andean and foreland producers are more gas-andcondensate prone and have reservoirs of all geologic ages.

\section{Hydrocarbon Geochemistry}

On average, older reservoirs generally are more oil-prone and have lower oil gravities, although both Tertiary and Carboniferous reservoirs do record nearly the full range (27$71^{\circ} \mathrm{API}$ ) observed in the province (Petroconsultants, 1996). Gas-oil ratios (GOR) also have significant variability $(100-73000 \mathrm{cfg} / \mathrm{bo})$, but higher values typically characterize older reservoirs. Diasterane $\left(\mathrm{C}_{27}-\mathrm{C}_{29}\right)$ biomarkers distinguish most produced and seep 


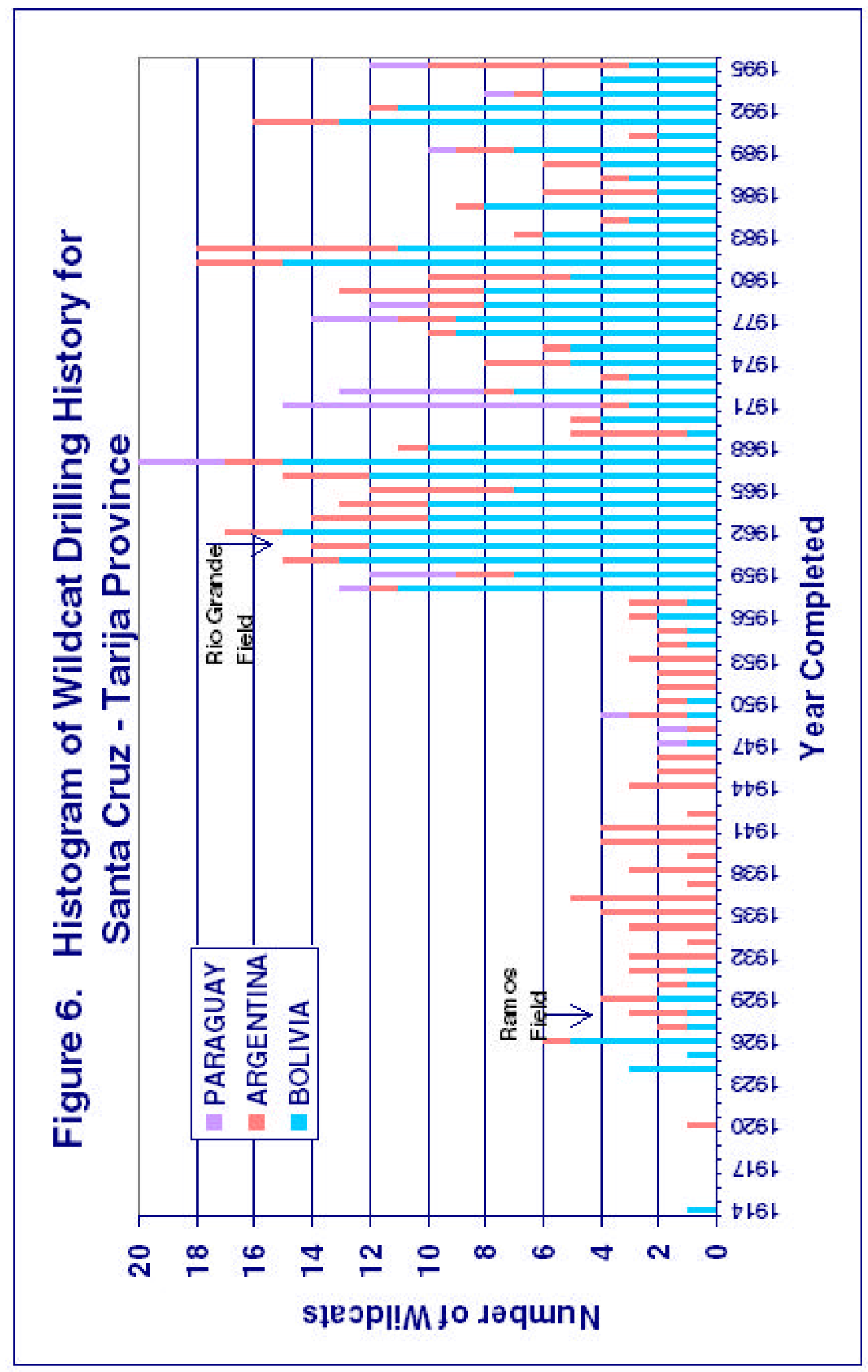


hydrocarbons as having been sourced by the same middle Paleozoic shales (Dunn and others, 1995), and they are further distinguished from Cretaceous sources south of this province by a low gammacerane index (Paleozoic 2 versus Cretaceous 30; ten Haven, 1996).

Migration-fractionation is proposed (Illich and others, 1981) to explain the gravity trend with reservoir age. Younger-reservoired, higher gravity hydrocarbons have significantly lower concentrations of normal paraffins, slightly lower concentrations of aromatics, and greater concentrations of isoparaffins and cycloparaffins. Such differences cannot be explained satisfactorily by differing thermal, burial and expulsion histories; regional source character variability; shallow bacterial degradation due to fresher water; or a segregation-migration process ${ }^{3}$. Migration-fractionation results from differing solubilities of major hydrocarbon groups in water; i.e., cross-stratigraphic movement of fluids with imperfect exsolution.

Others propose that some gravity differences associated with reservoir age can be explained by different generation and entrapment histories, particularly along the Boomerang Hills depositional paleohinge, which underwent periodic episodes of extensional faulting nearly parallel in trend with later Andean compressional folding and faulting (Welsink and others, 1995). The Silurian source rock, geochemically similar to its Devonian counterpart, locally entered the oil window as early as Carboniferous time. Low gravity oils (35-40 $\mathrm{API}$ ) in Boomerang Devonian reservoirs could be relict accumulations of earlier phases of oil generation from deeper parts of the old Paleozoic basin. Baby and others (1995) believe the marine oil source rock has such low initial potential that generated oil does not expel easily, but the lighter compounds do expel.

\section{Petroleum System Characteristics}

Prominent Silurian and Devonian shale detachment horizons probably create lateral migration routes, in addition to unconformity surfaces prominent around the margins of the province. Belotti and others (1995) report the existence of two Los Monos stratigraphic zones of high fluid pressure that likely enable expulsion in both upward and downward directions, explaining charge in older reservoirs when no lateral juxtaposition occurs. The presence of both mature and immature source rocks on uplifted thrust segments suggests that both vertical and limited lateral migration are required to charge the folded and faulted structures.

Ultimately, 4.1 BBOE are predicted to be recovered from known fields (Petroconsultants, 1996). Table 1 illustrates the gas-prone nature of the known reserves, their distribution in structural traps, and the early production emphasis on oil (\% of each commodity produced). Also shown is the dominance of Carboniferous reservoirs. More than half the known reserves are difficult to allocate to reservoirs because multiple horizons produce and inadequate data are published to make those distinctions.

\footnotetext{
${ }^{3}$ fractionation by retrograde hydrocarbon condensation from a moving gas phase
} 


\section{Table 1. Santa Cruz - Tarija Province \\ Production and Reservoir Statistics \\ (based on data from Petroconsultants, 1996)}

\begin{tabular}{|c|c|c|c|c|}
\hline \multirow[b]{3}{*}{ ENTIRE PROVINCE } & \multirow[b]{2}{*}{ MMBOE Ultimate } & \multicolumn{3}{|c|}{ HYDROCARBON TYPE } \\
\hline & & Oil (MMBOE) & Gas (BCF/MMBOE) & Cond (MMBOE) \\
\hline & 4089 & $\begin{array}{c}328(8 \%) \\
78 \% \text { produced }\end{array}$ & $\begin{array}{c}18775 / 3128(77 \%) \\
37 \% \text { produced }\end{array}$ & $\begin{array}{l}633(15 \%) \\
38 \% \text { produced }\end{array}$ \\
\hline "GEOLOGIC PROVINCE" * & & & & \\
\hline $\begin{array}{l}\text { SubAndean } \\
\text { (all "structural" traps) }\end{array}$ & 477 & $\begin{array}{l}130(27 \%) \\
96 \% \text { produced }\end{array}$ & $\begin{array}{c}1779 / 296(62 \%) \\
12 \% \text { produced }\end{array}$ & $\begin{array}{l}51(11 \%) \\
4 \% \text { produced }\end{array}$ \\
\hline $\begin{array}{c}\text { Foothills } \\
\text { (all "structural" traps) }\end{array}$ & 2200 & $\begin{array}{c}159(7 \%) \\
73 \% \text { produced }\end{array}$ & $\begin{array}{c}9980 \text { / } 1663(76 \%) \\
54 \% \text { produced }\end{array}$ & $\begin{array}{l}377(17 \%) \\
53 \% \text { produced }\end{array}$ \\
\hline $\begin{array}{l}\text { Tarija Basin } \\
\text { (mostly "anticline" traps) }\end{array}$ & 1349 & $\begin{array}{c}30(2 \%) \\
34 \% \text { produced }\end{array}$ & $\begin{array}{c}6745 / 1124(83 \%) \\
17 \% \text { produced }\end{array}$ & $\begin{array}{l}194(15 \%) \\
18 \% \text { produced }\end{array}$ \\
\hline $\begin{array}{c}\text { Chaco Basin } \\
\text { (mostly "anticline" traps) }\end{array}$ & 50 & $\begin{array}{c}4(8 \%) \\
40 \% \text { produced }\end{array}$ & $\begin{array}{l}224 / 37 \text { ( } 74 \%) \\
52 \% \text { produced }\end{array}$ & $\begin{array}{c}9(18 \%) \\
48 \% \text { produced }\end{array}$ \\
\hline $\begin{array}{l}\text { Carandaity Basin (Paraguay) } \\
\text { (trap type not disclosed) }\end{array}$ & 2 & 0 & $\begin{array}{c}10.5 / 1.75(100 \%) \\
\text { none produced }\end{array}$ & 0 \\
\hline $\begin{array}{l}\text { Beni Basin (far NW) } \\
\text { ("anticline" trap) }\end{array}$ & 5 & 0 & $\begin{array}{l}25 / 4 \text { ( } 40 \%) \\
\text { none produced }\end{array}$ & $1(20 \%)$ \\
\hline $\begin{array}{l}\text { Michicola - Boqueron (far SW) } \\
\text { ("recumbent fold" trap) }\end{array}$ & 6 & $\begin{array}{l}4.4(71 \%) \\
90 \% \text { produced }\end{array}$ & $\begin{array}{l}11 / 1.8(29 \%) \\
97 \% \text { produced }\end{array}$ & 0 \\
\hline
\end{tabular}

\begin{tabular}{|c|c||c|c|}
\hline AGE HORIZON & MMBOE Ultimate & $\begin{array}{c}\text { Average } \\
\text { Porosity (\%) }\end{array}$ & $\begin{array}{c}\text { Average } \\
\text { Permeability (md) }\end{array}$ \\
\hline INDETERMINABLE ALLOCATION & $\mathbf{2 3 2 3 ( 5 7 \% )}$ & & \\
Tertiary & $\mathbf{1 1 6}(3 \%)$ & 19 & $165(96)$ \\
Cretaceous & $\mathbf{7 7}(2 \%)$ & 22 & $138(116)$ \\
Permo-Triassic & $\mathbf{1}$ (trace) & 23 & $200(200)$ \\
Carboniferous & $\mathbf{1 0 4 9 ( 2 5 \% )}$ & 20 & $156(119)$ \\
Devonian & $\mathbf{4 5 1}(\mathbf{1 1} \%)$ & 11 & $<10(<10)$ \\
Silurian & $\mathbf{7 2 ( 2 \% )}$ & 10 & $50(50)$ \\
\hline
\end{tabular}




\section{SOURCE ROCK}

Devonian and Silurian shale source rocks (Figure 7) were deposited in a semi-restricted, marine extensional basin covering most of the province. Both horizons are preserved throughout the area with thicknesses ranging from many hundred to several thousand meters each, but Devonian source rocks are typically thicker. Maximum SiluroDevonian composite thickness is $4 \mathrm{~km}$. Source rock quality possibly deteriorates to some degree because of lithologic variability near depositional basin margins (e.g., Brazilian shield, Asuncion arch, westward in the thrust belt) and perhaps over the central Chaco high, which was prominent and exposed by the Carboniferous period.

Silurian and Devonian shales are geochemically similar and locally have generated oil since as early as the early Carboniferous period (Baby and others, 1995; Dunn and others, 1995; Franca and others, 1995; Starck, 1995; Welsink and others, 1995; Wiens, 1995). Both intervals are type II to type III, mixed oil- and gas-prone source rocks. Although best TOCs are just 2 wt \%, the shales have significant thicknesses. Los Monos hydrogen indices cluster in the 100-300 range but reach $500 \mathrm{mgHC} / \mathrm{gTOC}$ (Dunn and others, 1995). Corresponding oxygen indices cluster in the 10-50 range but can approach 300 $\mathrm{mgCO} 2 / \mathrm{gTOC}$.

Devonian Los Monos shales are the thickest identifiable and correlatable known source rocks in the Santa Cruz - Tarija Province. Overall, they have had the most favorable burial histories, with hydrocarbon generation windows coinciding with or post-dating the Tertiary time of major compressional trap formation.

\section{OVERBURDEN ROCK}

Regionally variable thermal gradients, post-Devonian isopachs, and Andean loading history determine when Siluro-Devonian source rocks matured - ranging from early Carboniferous to the present in different parts of the province (Figure 7, Figures 8a, 8b, 8c). Paleozoic and younger basin axes, where thickest depositional overburden exists, were near the eastern sub-Andean foothills or the present foreland (Dunn and others, 1995), but tectonic burial increased westward through the fold and thrust belt.

Carboniferous overburden varies laterally along the eastern sub-Andean from $<1300$ meters in the northern area, to 1600-2000 meters in the central region, to 1300-1600 meters adjacent to Argentina (Beer and Lopez P., 1993). It also depositionally thins into the western sub-Andean, to the north against the ancestral Brazilian shield, to the east against the Asuncion arch, and around the foreland's central Chaco high (Carboniferous Izozog arch) in Paraguay. Carboniferous glacially supplied siliciclastics were deposited in alluvial to marine settings.

Shallow marine to continental Permo-Triassic strata are thin (mostly $<1 \mathrm{~km}$ ) in the subAndean and terminate in the foreland west of the central Chaco high. Jurassic rocks are mostly absent from the province. Cretaceous marine to non-marine rocks are also typically $<1 \mathrm{~km}$ thick with depositional margins resembling those of the Carboniferous. Cenozoic continental foreland fill ranges from 1-4.5 km, thinner to the west and onto the present forebulge axis in the eastern part of the province (Horton and DeCelles, 1997). 


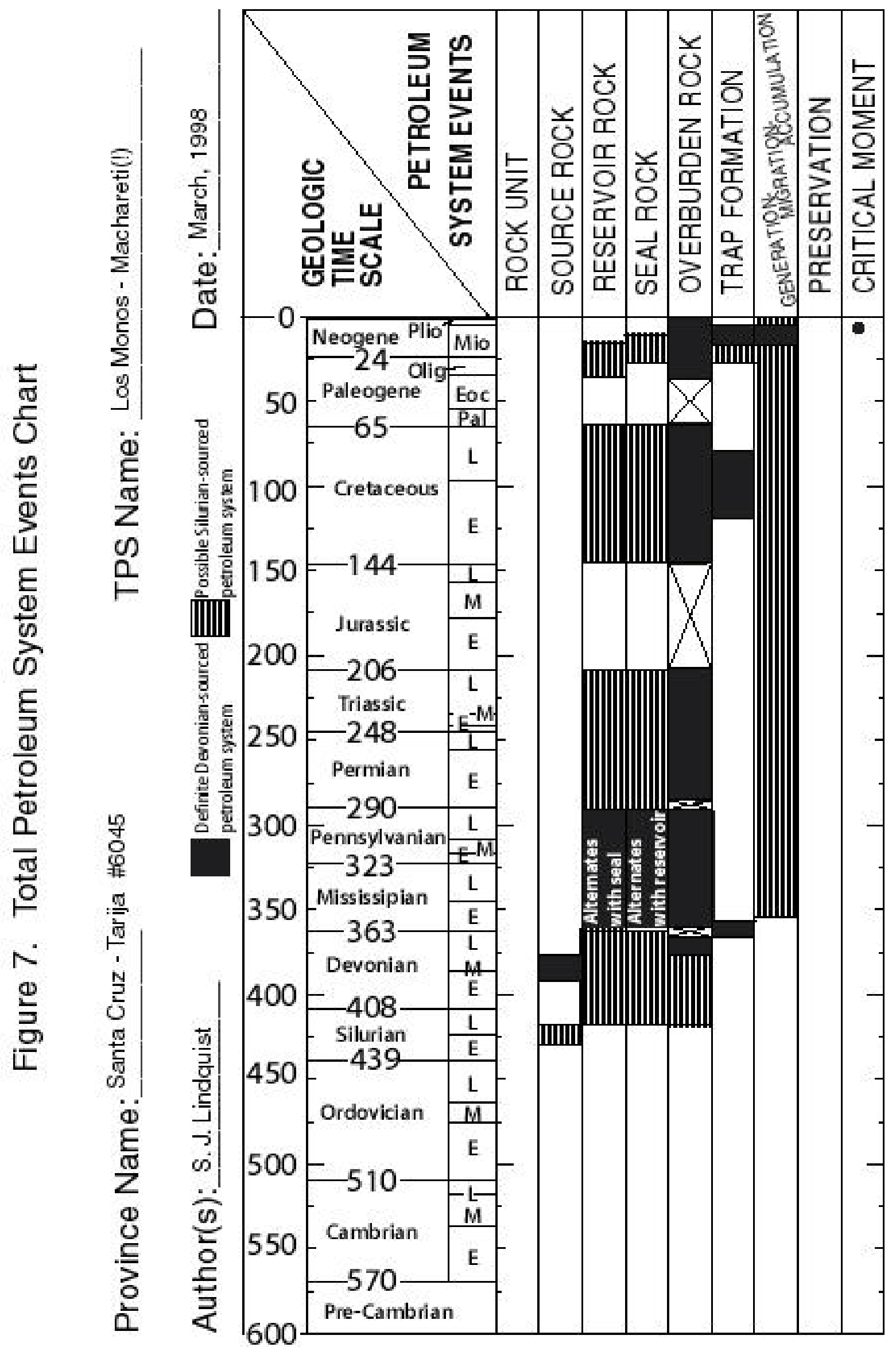




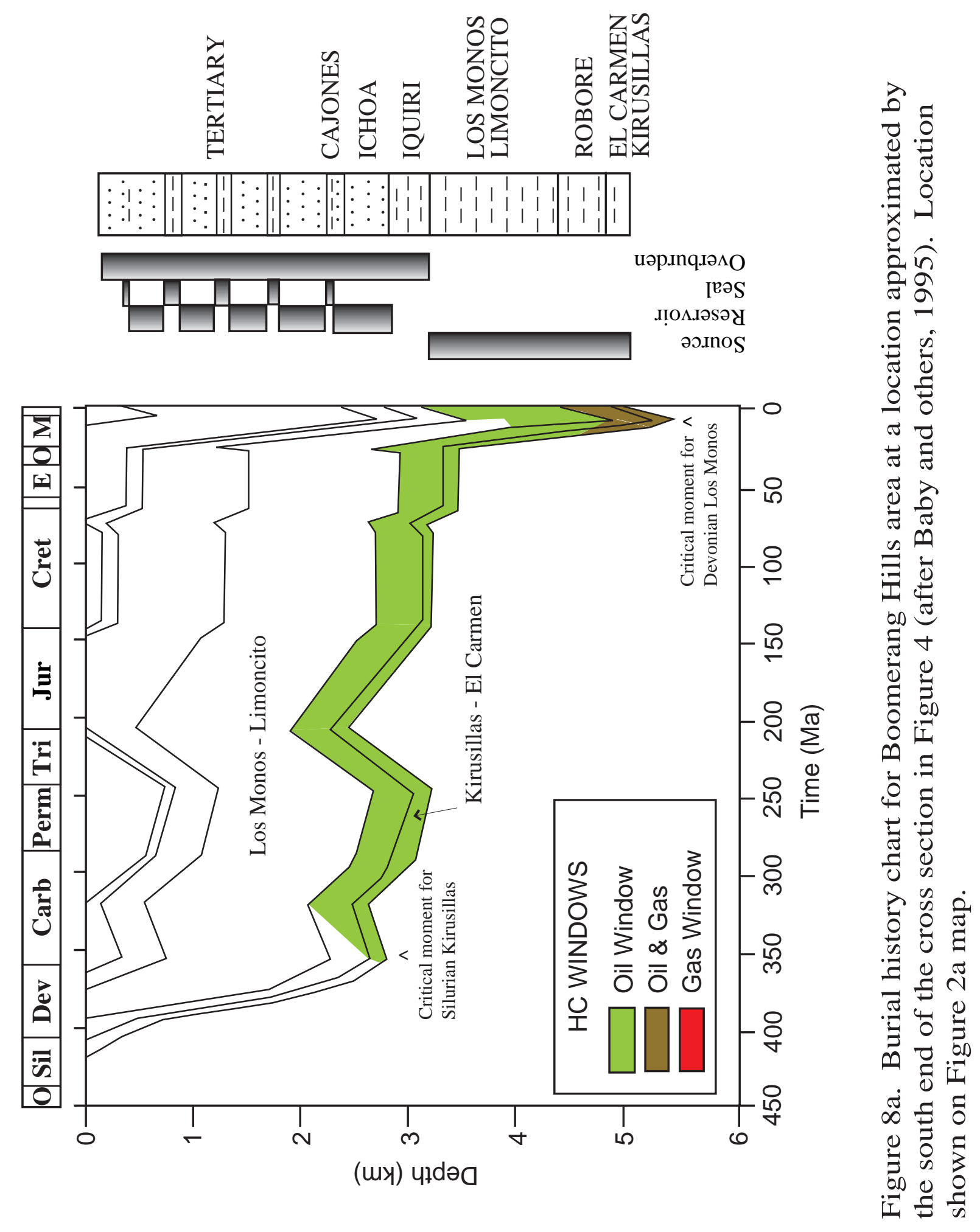




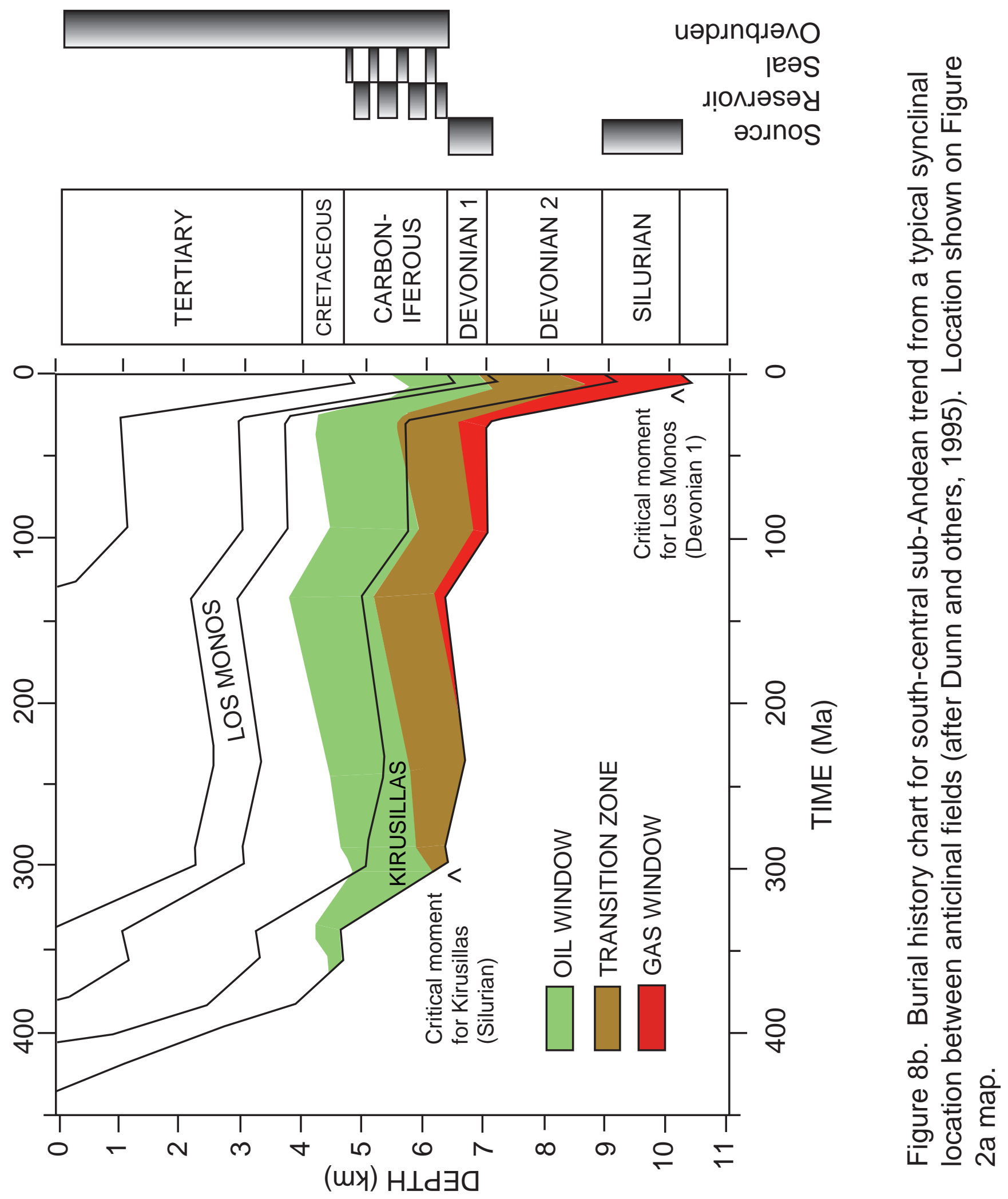




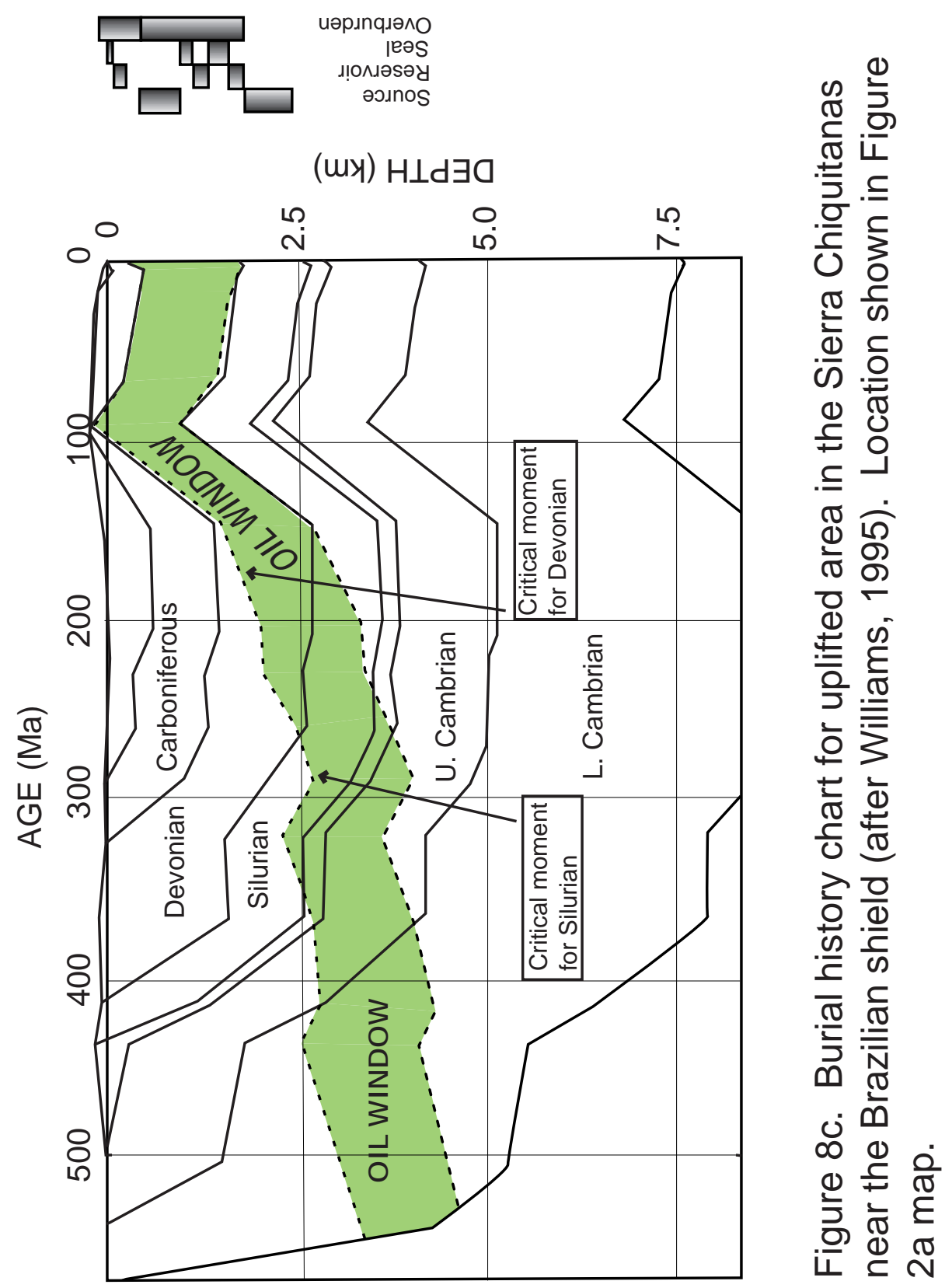




\section{THERMAL GRADIENTS}

Santa Cruz - Tarija thermal gradients vary regionally. The foreland has higher gradients than the sub-Andean thrust belt. Gradients in basement uplifts like the central Chaco high are higher than in the foreland sub-basins. Sub-Andean gradients range from 11-19 ${ }^{\circ} \mathrm{C} / \mathrm{km}\left(0.62-1.07{ }^{\circ} \mathrm{F} / 100 \mathrm{ft}\right)$ (Petroconsultants, 1996). The northwestern margin of the province at Boomerang Hills is typified by $25^{\circ} \mathrm{C} / \mathrm{km}\left(1.4^{\circ} \mathrm{F} / 100 \mathrm{ft}\right)$ (Baby and others, 1995). The northeastern province margin at the Sierras Chiquitanas averages $36{ }^{\circ} \mathrm{C} / \mathrm{km}$ $\left(2^{\circ} \mathrm{F} / 100 \mathrm{ft}\right)($ Williams, 1995). Wiens (1995) notes "high" thermal gradients of 7-9 ${ }^{\circ} \mathrm{C} / \mathrm{km}\left(0.4-0.5^{\circ} \mathrm{F} / 100 \mathrm{ft}\right.$ ) (sic) on the Paraguayan central Chaco high where thermal maturity locally reaches metamorphic grade and local magmatic activity is postulated. Wien's reported gradients are probably misstated too low by a factor of 10 .

Where thermal gradients are 25 to $40{ }^{\circ} \mathrm{C} / \mathrm{km}$ (1.4 to $\left.2.2^{\circ} \mathrm{F} / 100 \mathrm{ft}\right), 2.5-4 \mathrm{~km}$ of overburden thickness is needed for maturation (Baby and others, 1995; Williams, 1995). Lesser overburden is required in the foreland around the hotter central Chaco high. The sub-Andean with lowest thermal gradients is presently mature to oil with $5.5 \mathrm{~km}$ overburden (Dunn and others, 1995).

Silurian sources are now overmature in outcrops west of this province and likely mature for gas in deepest parts of the foreland. If traps were present and not subsequently lost, Silurian-sourced oil accumulations could be preserved in old Carboniferous-aged extensional blocks. Silurian capability for recent gas generation is doubtful because of the long period of time its source rocks were at a mature stage for oil (Figure 8a).

Because of overburden variability, central sub-Andean Devonian source rocks could have expelled as early as $270 \mathrm{Ma}$; whereas southern Bolivian counterparts adjacent to Argentina probably expelled about $150 \mathrm{Ma}$ and northern counterparts $10 \mathrm{Ma}$ (Beer and Lopez P., 1993). Devonian source rocks in the sparsely explored western sub-Andean would have had an expulsion history favorable for entrapment in Andean-age structural traps. The Argentinian sub-Andean probably did not expel significant hydrocarbon until late Tertiary (Andean) or later time, but local maturation could have begun as early as the Jurassic period (Starck, 1995). Devonian source rocks on margins of hotter foreland basement highs could be presently in the oil window.

\section{TRAP STYLE OF OIL AND GAS FIELDS}

\section{$\underline{\text { Trap Location and Development }}$}

Santa Cruz - Tarija discovered fields are dominantly on sub-Andean anticlines and thrusted anticlines (Table 1, Figure 2a). Silurian and Devonian detachment surfaces enabled the deformation to be thin-skinned and laterally extensive. Deformation progressed eastwardly through time, and consistent changes in deformational style related both to maturity of deformation and to subtle stratigraphic variations impacting detachment surfaces - occur from west to east (Belotti and others, 1995; Dunn and others, 1995). The underexplored and more oil-prone western sub-Andean is geologically older, structurally more mature and complex, and has an extra level of 
detachment than the eastern sub-Andean. Major accumulations in Argentina exist where fault-bend folds overlie major step thrusts (Belotti and others, 1995). Stratigraphic complexities probably impacted hydrocarbon distribution and complicate field development locally. Reserve growth probably will occur in existing fields of both subAndean trends with future detailed delineations of minor faulting and reservoir compartmentalization.

Historic Santa Cruz - Tarija extensional trends are parallel with the Brazilian shield front (northwest/southeast) and the Michicola arch (east-northeast/west-southwest). Unconformities and sedimentary onlap wedges on the old Brazilian shield also play important roles in trapping hydrocarbons at this northern basin edge and in contributing to the creation of structural closures here during Andean compressional deformation (Welsink and others, 1995).

Extensional Paleozoic block faults were created and/or rejuvenated periodically in the Chaco-Tarija basin (Welsink and others, 1995), creating new force-fold structures and either preserving or destroying pre-existing ones. Such traps were necessary to potentially collect earliest (Carboniferous) phases of oil migration (Figure 7). Only one well northeast of Boomerang Hills has tested this pre-Andean trap concept successfully to date.

Although earliest compression and shortening began in late Cretaceous to Paleocene time in the western Andes Mountains, major folding and trap development occurred here 10 Ma or less (Miocene and Pliocene). The continuing eastward migration of the orogenic complex through time (Horton and Decelles, 1997) and the regional variability of thermal gradients have created a mechanism for a continuum of maturation and entrapment, both in younger structures and in onlapping stratigraphic wedges. Foreland high thermal gradients result in shallow maturation profiles and potentially recent accumulations if seals are adequate.

Underdeveloped and underexplored trap concepts known to exist from seismic data in the easterly foreland area are 1) simple stratigraphic truncation against local and regional highs, and 2) forced folds overlying extensional fault blocks of various ages.

\section{$\underline{\text { Reservoir Distribution of Oil and Gas }}$}

Most ultimate recoverable reserves are in fields with multiple producing horizons, but $43 \%$ can be allocated to individual producing strata based on porosity, net thickness, and water saturation considerations (Table 1) (Petroconsultants, 1996). Twenty-five percent of ultimate recoverable reserves are definitively within Carboniferous reservoirs, $11 \%$ in Devonian counterparts, and just 2-3\% each in the Silurian, Tertiary and Cretaceous section, with a trace in Permo-Triassic rocks. Twenty-seven percent of Santa Cruz Tarija known recoverable reserves are in multiple horizons within the two largest fields, and Carboniferous sandstones contribute significant production to at least one of those fields. 


\section{Discovery history}

In the decade following the Bermejo field discovery of 1924, generally 1 to 3 fields were discovered per year by Argentina and/or Bolivia. Following an unsuccessful period until 1947, both countries alternated finding a field every year or two until around 1960 when Bolivia's success increased in conjunction with its increased exploration drilling (Figure 6). Periodically, as many as five fields were discovered in one year. Argentina, although at a slower drilling schedule, also continued sporadically to add one or two discovered fields annually to its small sub-Andean area through the present. Paraguay's two contiguous productive areas were discovered in 1959 and the mid 1990s.

\section{RESERVOIR ROCK}

\section{Geographic and Stratigraphic Location}

Known Santa Cruz - Tarija reservoirs include Silurian and younger rocks. SiluroDevonian reservoirs exist in the entire sub-Andean trend and comprise the only known production in Paraguay (northwestern area). Amalgamated channel-like sandstones with predictable trends abound in what was the Carboniferous depositional basin (excludes the central Chaco high), and such sandstones contain most reserves (Figures 1 and 7, Table 1). Carboniferous strata produce in two Bolivian fields east of the mountain front and within the entire sub-Andean trend, south of where they are regionally truncated (just south of $17^{\circ}$ south latitude and south of the Boomerang Hills).

Permo-Triassic reservoirs are rare but evenly dispersed along the Bolivian sub-Andean fold and thrust belt between $18^{\circ}$ and $21.5^{\circ}$ south latitude. Cretaceous and Tertiary reservoirs also are similarly distributed, with significant representation in Boomerang Hills (where Siluro-Devonian sandstones produce along their truncation edge). The Argentinian portion of the fold and thrust region is dominated by Devonian and Carboniferous reservoirs, although two fields also have Tertiary completions.

\section{Physical and Depositional Characteristics}

Lower Paleozoic rocks in Santa Cruz - Tarija are marine to deltaic sandstones and shales. Multiple provenance areas surrounded the paleo-basin at different points in time, although the persistent northern Brazilian shield and eastern Asuncion arch often supplied rather limited volumes of sediment compared to the western Arequipa massif. Deepest parts of the marine basins were farther northwest into Peru (and toward the paleo-Pacific Ocean). Despite potentially great thicknesses, pre-Silurian sandstones are considered non-reservoir rocks because of low porosity and permeability resulting from their burial and tectonic histories. Silurian and Devonian reservoirs have as much as several hundred meters net-pay thickness in sub-Andean folds, and generally several meters to tens of meters net-pay thickness along the Boomerang Hills truncation (Petroconsultants, 1996).

Carboniferous proximal mountain glaciers supplied as much as $2 \mathrm{~km}$ sedimentary strata to a basin eventually filled - from southeast to northwest - with fluvial to submarine siliciclastic channel deposits. Sixty to more than $80 \%$ of sub-Andean production has 
been attributed to Carboniferous reservoirs (Eyles and others, 1995; Franca and others, 1995). Orientation of anastomosing sand-filled channels was impacted by basement structure. Individual channels on outcrop are tens of $\mathrm{km}$ wide and several hundred $\mathrm{km}$ long, and amalgamation is common (Eyles and others, 1995). Significant Carboniferous deposits are lacking on the Paraguayan central Chaco high (Carboniferous Izozog arch). Sand trends are southeast-northwest in the Curupaity sub-basin adjacent to the Brazilian shield and south-north in the Carandaity sub-basin adjacent to the present sub-Andean fold belt. Carboniferous reservoirs average several meters to tens of meters net-pay thicknesses, with a recorded maximum of 115 meters (Petroconsultants, 1996).

Reservoirs younger than Carboniferous also have several meters to tens of meters netcompletion thicknesses. Typically thin Permo-Triassic reservoirs are marine to continental in origin, and thicker Cretaceous and Tertiary counterparts are progressively more continental in character with younger age.

\section{Reservoir properties}

Compared with younger reservoir rocks, pre-Carboniferous horizons have low overall porosity and permeability (Table 1) and probable fracture assisted deliverability, particularly in southern sub-Andean fields. At the northern sub-Andean truncation edge (Boomerang Hills), Siluro-Devonian production is from sandstones with field averages of $10-15 \%$ porosity and as much as 50 md permeability. Farther south in the sub-Andean fold belt, the porosity minimum is $4 \%$ and the permeability minimum is tenths of millidarcies. Average porosity for Carboniferous fields ranges from 10-26\%, and average permeability from 11-450 md. The few reported Permo-Triassic reservoirs are characterized by $21-25 \%$ porosity and 200 md permeability. Producing Cretaceous fields average $17-25 \%$ porosity with tens to $200 \mathrm{md}$ permeability, and Tertiary fields average $15-25 \%$ porosity and several to 271 md permeability.

\section{Underexplored reservoir rocks}

All stratigraphic horizons are underexplored in the foreland basin of the Santa Cruz Tarija Province because of the paucity of well penetrations there. Forced folds overlying extensional block faults (some reactivated periodically and inverted) and truncation/onlap relationships exist around the old basin margins and the central Chaco high of Paraguay. The western sub-Andean trend also is sparsely drilled, but reservoirs there are likely to be older because of increased tectonic uplift and resultant erosion in a westerly direction through the fold and thrust belt.

\section{SEAL ROCK}

Regional and local Paleozoic marine shales, regularly alternating with sandstone reservoir rocks, provide the necessary sealing capacity for many known Santa Cruz Tarija hydrocarbon accumulations (Figure 7). Seal thicknesses range from as little as approximately ten meters for some intraformational strata to more than 1000 meters for regional horizons such as the Los Monos source rock interval. The ultimate seal for the most important Devonian reservoir rocks in Ramos (the largest Santa Cruz - Tarija field) is a 2-km-thick "diapir" of highly contorted and high-pressured Los Monos shale in the 
core of the fold, which creates a box-fold geometry for younger strata above (Belotti and others, 1995).

Some Carboniferous seals are actually poorly sorted glacial diamictites tens of meters to hundreds of meters thick. Somewhat lesser-quality marine to marginal marine shales also are adequate seals within the Mesozoic and Cenozoic section - particularly the Triassic Ipaguazu Formation, which has some evaporite content, and the Miocene Yecua Formation shales.

\section{ASSESSMENT UNITS}

Santa Cruz - Tarija has at least six geologically distinct areas - three in the fold and thrust belt and three in the foreland basin - that are grouped here into the following three assessment units: Sub-Andean Fold and Thrust Belt (\#60450101), Foreland Basins (\#60450102), and Foreland Central Chaco High (\#60450103) (Figure 2b).

\section{$\underline{\text { Sub-Andean Fold and Thrust Belt \#60450101 }}$}

Within the thrusted sub-Andean folds, the western half is geologically older, structurally more complex, less densely explored, and more oil prone than its eastern counterpart. Some investigators might also sudivide the eastern sub-Andean along a north-south transect, based on differences in burial history and expulsion timing, as previously discussed. Reservoirs of all ages produce in the fold and thrust belt. Production in the sub-Andean trend north of the Carboniferous truncation (Figure 2b) is limited to nonCarboniferous reservoirs, and it is characterized with relict extensional fabrics that were reactivated during the Andean compressional event. This small area north of the Carboniferous truncation also has established production, but a slightly different fieldsize distribution than the remaining fold and thrust belt; it is here combined with the subAndean assessment unit because of its limited areal extent.

\section{Foreland Basins \#60450102}

The foreland region contains a sub-basin (Curupaity) parallel with the Brazilian shield on the province northeastern margin and extending southward along the province eastern margin (Figures $2 \mathrm{a}$ and $2 \mathrm{~b}$ ). Although the basinal axis has a lower thermal gradient than the surrounding basement highs, its gradient is higher than that in the fold and thrust belt. All potential reservoir rocks are present, and stratigraphic onlaps and truncations border the sub-basin margins where thermal gradients are higher. Northwest-southeast trending extensional fabrics and associated structural closures are expected. Another sub-basin (Carandaity) is parallel with and just eastward of the sub-Andean folds (Figures 2a and $2 b$ ). Both these sub-basins have limited production and are combined into this one frontier assessment unit where all reservoirs - including those of Carboniferous ages are likely preserved.

\section{Foreland Central Chaco High \#60450103}

The third assessment unit is hypothetical, with hydrocarbon shows but no established production. It has been a persistent structural high, with shallow burial histories but 
significantly high thermal gradients, at least in its most recent past. Although age equivalents of the source rocks are present, they might have more terrigenous character and poorer source-rock quality here. Carboniferous reservoirs are absent. Traps and seals are more questionable in quality than in the "Foreland Basin" assessment unit. Most of this assessment unit is within Paraguay, and its boundary coincides with the zero edge of Carboniferous strata (Figures $2 \mathrm{a}$ and $2 \mathrm{~b}$ ).

\section{SELECTED REFERENCES}

Baby, P., Moretti, I., Guillier, B., Limachi, R., Mendez, E., Oller, J., and Specht, M., 1995, Petroleum system of the northern and central Bolivian sub-Andean zone, in Tankard, A.J., Suarez S., R., and Welsink, H.J., eds., Petroleum basins of South America: American Association of Petroleum Geologists Memoir 62, p. 445-458.

Beer, J.A., and Lopez P., O., 1993, Paleozoic expulsion in Bolivia - its influence on field size and distribution: American Association of Petroleum Geologists Bulletin, v. 77 , no. 2 , p. 306.

Belotti, H.J., Saccavino, L.L., and Schachner, G.A., 1995, Structural styles and petroleum occurrence in the sub-Andean fold and thrust belt of northern Argentina, in Tankard, A.J., Suarez S., R., and Welsink, H.J., eds., Petroleum basins of South America: American Association of Petroleum Geologists Memoir 62, p. 545-555.

Boyd, G.H., 1977, Exploration activity reviving rapidly in western and northern Paraguay: Oil and Gas Journal (June 13, 1977), p. 96-98.

Dunn, J.F., Hartshorn, K.G., and Hartshorn, P.W., 1995, Structural styles and hydrocarbon potential of the sub-Andean thrust belt of southern Bolivia, in Tankard, A.J., Suarez S., R., and Welsink, H.J., eds., Petroleum basins of South America: American Association of Petroleum Geologists Memoir 62, p. 523-543.

Eyles, N., Gonzalez Bonorino, G., Franca, A.B., Eyles, C.H., and Lopez Paulsen, O., 1995, Hydrocarbon-bearing late Paleozoic glaciated basins of southern and central South America, in Tankard, A.J., Suarez S., R., and Welsink, H.J., eds., Petroleum basins of South America: American Association of Petroleum Geologists Memoir 62, p. 165183.

Franca, A.B., Milani, E.J., Schneider, R.L., Lopez P., O., Lopez M., J., Suarez S.,

R., Santa Ana, H., Wiens, F., Ferreiro, O., Rossello, E.A., Bianucci, H.A., Flores, R.F.A., Vistalli, M.C., Fernandez-Seveso, F., Fuenzalida, R.P., and Munoz, N., 1995, Phanerozoic correlation in southern South America, in Tankard, A.J., Suarez S., R., and Welsink, H.J., eds., Petroleum basins of South America: American Association of Petroleum Geologists Memoir 62, p. 129-161.

Gohrbandt, K.H.A., Paleozoic paleogeographic and depositional developments on the central proto-Pacific margin of Gondwana: their importance to hydrocarbon accumulation: Journal of South American Earth Sciences, v. 6, no. 4, p. 267-287. 
Horton, B.K., and DeCelles, P.G., 1997, The modern foreland basin system adjacent to the central Andes: Geology, v. 25, no. 10, p. 895-898.

Illich, H.A., Haney, F.R., and Mendoza, M., 1981, Geochemistry of oil from Santa Cruz Basin, Bolivia: case study of migration-fractionation: American Association of Petroleum Geologists Bulletin, v. 65, no. 11, p. 2388-2402.

Klett, T.R., Ahlbrandt, T.S., Schmoker, J.W., and Dolton, G.L., 1997, Ranking of

the world's oil and gas provinces by known petroleum volumes: U.S. Geological Survey Open File Report 97-463, CD Rom.

Magoon, L.B., and Dow, W.G., 1994, The petroleum system, in Magoon, L.B., and Dow, W.G., eds., The Petroleum System - from Source to Trap: A.A.P.G. Memoir 60 , p. 3-23.

Petroconsultants, 1996, Petroleum exploration and production database: Houston, Texas, Petroconsultants, Inc., [database available from Petroconsultants, Inc., at P.O. Box 740619, 6600 Sands Point Drive, Houston, TX, 77274-0619, USA or P.O. Box 152, 24 Chemin de la Mairie, 1258 Perly, Geneva, Switzerland].

Pindell, J.L., and Tabbutt, K.D., 1995, Mesozoic-Cenozoic Andean paleogeography and regional controls on hydrocarbon systems, in Tankard, A.J., Suarez S., R., and Welsink, H.J., eds., Petroleum basins of South America: American Association of Petroleum Geologists Memoir 62, p. 101-128.

Starck, D., 1995, Silurian-Jurassic stratigraphy and basin evolution of northwestern Argentina, in Tankard, A.J., Suarez S., R., and Welsink, H.J., Petroleum basins of South America: American Association of Petroleum Geologists Memoir 62, p. 251-267.

Tankard, A.J., Suarez S., R., and Welsink, H.J., eds., 1995, Petroleum basins of South America, American Association of Petroleum Geologists Memoir 62: U.S.A., American Association of Petroleum Geologists, Yacimientos Petroliferos Fiscales Bolivianos, and Academia Nacional de Ciencias de Bolivia, 792 p.

Tankard, A.J., Uliana, M.A., Welsink, H.J., Ramos, V.A., Turic, M., Franca, A.B., Milani, E.J., de Brito Neves, B.B., Eyles, N., Skarmeta, J., Santa Ana, H., Wiens, F., Cirbian, M., Lopez Paulsen, O., Germs, G.J.B., De Wit, M.J., Machacha, T., Miller, R. McG., 1995, Structural and tectonic controls of basin evolution in southwestern Gondwana during the Phanerozoic, in Tankard, A.J., Suarez S., R., and Welsink, H.J., eds., Petroleum basins of South America: American Association of Petroleum Geologists Memoir 62, p. 5-52.

ten Haven, H.L., 1996, Applications and limitations of Mango's light hydrocarbon parameters in petroleum correlation studies: Organic Geochemistry, v. 24, no. 10/11, p. 957-976. 
Urien, C.M., Zambrano, J.J., and Yrigoyen, M.R., 1995, Petroleum basins of southern South America: an overview, in Tankard, A.J., Suarez S., R., and Welsink, H.J., eds., Petroleum basins of South America: American Association of Petroleum Geologists Memoir 62, p. 63-77.

Welsink, H.J., Franco M., A., and Oviedo G., C., 1995, Andean and pre-Andean deformation, Boomerang Hills area, Bolivia, in Tankard, A.J., Suarez S., R., and Welsink, H.J., eds., Petroleum basins of South America: American Association of Petroleum Geologists Memoir 62, p. 481-489.

Wiens, F., 1995, Phanerozoic tectonics and sedimentation in the Chaco Basin of Paraguay, with comments on hydrocarbon potential, in Tankard, A.J., Suarez S., R., and Welsink, H.J., eds., Petroleum basins of South America: American Association of Petroleum Geologists Memoir 62, p. 185-205.

Williams, K.E., 1995, Tectonic subsidence analysis and Paleozoic paleogeography of Gondwana, in Tankard, A.J., Suarez S., R., and Welsink, H.J., eds., Petroleum basins of South America: American Association of Petroleum Geologists Memoir 62, p. 79-100. 